\title{
Lead bioremoval by Bacillus spp. Isolated from industrial wastewater
}

\author{
Fa'iza Kadhim Omran *
}

\author{
Harith J.Fahad Al-Mathkhury*
}

\author{
Received 20, June, 2010 \\ Accepted 26, October, 2010
}

\begin{abstract}
:
Four samples were collected from the wastewater of State Battery Manufacturing Company (SBMC); Babylon 2 factory in AL-Waziriya district, as triplicates. Physical and chemical measurements were carried out such as temperature, $\mathrm{pH}$, Lead concentrations and their ranges were: (19.5-34.5) ${ }^{\circ} \mathrm{C},(6.1-6.4)$ and (4.5-6.5) $\mathrm{mg} / \mathrm{L}$, respectively. Six dominant Bacillus spp. isolates were isolated from these samples; namely, Bacillus subtilis N1, Bacillus subtilis N2, Bacillus subtilis N3, Bacillus cereus N4, Bacillus cereus N5, Bacillus cereus N6. These isolates were capable of removing Lead from aqueous solutions in a capacity reached $27.6 \pm 1.4$, $10.1 \pm 1.7,74.5 \pm 0.7,8.93 \pm 2.8,8.1 \pm 3.5,1.6 \pm 0.7 \mathrm{mg} / \mathrm{L}$, respectively. Whereas cell walls, extracted from the same isolates, were able to remove $\mathrm{Pb}$ with high efficiency reached $77.7 \pm 0.3,18.6 \pm 1.2,9.5 \pm 0.7,42.4 \pm 6.3,9.9 \pm 0.9,6.7 \pm 2.1 \mathrm{mg} / \mathrm{L}$, respectively. This study showed that there is high variation $(\mathrm{P}<0.05)$ in the ability of the isolated bacteria for lead biosorption. However, Bacillus subtilis N3 were the most efficient $(\mathrm{P}<0.05)$ in uptaking the lead from its aqueous solutions in average of $(74.5$ $\pm 0.7) \mathrm{mg} / \mathrm{L}$ compared to other bacterial species. FTIR spectrum illustrated that hydroxyl groups, carboxyl, amide, and carbonyl are the major sites for $\mathrm{Pb}$ binding. Cell walls of $B$. subtilis were able to remove almost all $\mathrm{Pb}$ ions from the wastewater sample $(4.5 \mathrm{mg} / \mathrm{L})$ taken from the wastewater treatment unit in the State Battery Manufacturing Company.
\end{abstract}

Key words: Lead, bioremoval, Bacillus, wastewater.

\section{Introduction:}

Heavy metal pollution is of major concern, because it influences all living organisms in aquatic, terrestrial and air habitats. Discharging aqueous effluents containing relatively high levels of heavy metals such as lead, cadmium, nickel and chromium, render them as one of the major sources of water pollution [1]. Heavy metals differ from other toxic substances in that they are neither created nor destroyed by humans. Lead has been known for its toxicity for a long time as one of the most toxic heavy metals at very low concentration, which may cause health problems [2]. Conventional methods for heavy metal removal have several disadvantages, such as less effective removal of metal ions, high reagent requirements, high costs and the generation of toxic sludges [3].These limitations are forcing the scientists to study efficient, cost effective, non problematic, as well as, eco-friendly new technologies for the removal of toxic and precious metals from wastewater.

Biosorption represents a novel technology suitable for the treatment of metal - contaminated effluents [4]. It is well known that biological materials have advantages over many chemical treatments, since they are usually friendlier to the environment and do not produce toxic wastes [5]. Some

*University of Baghdad, College of Science, Department of Biology 
confusion has prevailed in the literature regarding the use of the terms "bioaccumulation" and "biosorption" based on the state of the biomass. Herein, therefore, bioaccumulation is defined as the uptake of toxicants by living cells. The toxicant can transport into the cell, accumulate intracellularly, across the cell membrane and through the cell metabolic cycle [6]. Conversely, biosorption can be defined as the passive uptake of toxicants by dead/inactive biological materials or by materials derived from biological sources [7].

The Gram positive cell wall is characterized by the presence of a very thick peptidoglycan layer, Embedded in the Gram positive cell wall are polyalcohols called teichoic acids. Teichoic acids give the Gram positive cell wall an overall negative charge due to the presence of phosphodiester bonds between teichoic acid monomers [8]. This makes them a potential heavy metal biosrobents.

The present work aimed to investigate the role of bacterial gram positive cell wall in lead bioremoval as well as to determine the reactive sites responsible for lead binding.

\section{Materials and methods \\ Lead standard solution}

In order to prepare lead standard solution of $10000 \mathrm{mg} / \mathrm{L}$ concentration, $15.985 \mathrm{gm}$ of lead nitrate $\mathrm{Pb}\left(\mathrm{NO}_{3}\right)_{2}$ were dissolved in $1000 \mathrm{ml}$ of Deionized DW. This solution was sterilized by filtration through $0.45 \mu \mathrm{m}$ membrane filter, and served as stock solution for further preparations.

\section{Sampling}

Four water samples (one sample per week, as triplicates) in a volume of 1 liter were collected from the main tank in the industrial wastewater treatment unit in babyl 2 factories at the State Battery Manufacturing
Company (SBMC) for the period of September 24th to October $25^{\text {th }}, 2008$, in sterile glassware containers. Each sample was divided into two parts; the first set was obtained to estimate the temperature, $\mathrm{pH}$ and lead concentration, while the other set was collected for bacterial isolation.

Temperature, $\mathrm{pH}$ and lead concentration of water samples were estimated in situ. The temperature was measured by a thermometer at (15-20) $\mathrm{cm}$ depth. $\mathrm{pH}$ was measured using a portable $\mathrm{pH}$ meter. The samples were digested by Digester (Buchi 430, Germany) following [9] to estimate the total lead.

\section{Isolation and identification of bacteria:}

All samples were cultured by streaking on MacConkey agar and blood agar, and incubated at $37{ }^{\circ} \mathrm{C}$. After $24 \mathrm{hr}$. the results were recorded and the grown colonies were subjected to microscopic examination and biochemical tests in order to identify them according to $2^{\text {nd }}$ edition of Bergey's manual [10].

\section{Preparation of Biosorbents:}

Bacterial isolates were propagated in brain heart infusion broth pH 7.2 incubated at $37^{\circ} \mathrm{C}$ for 24 hr. Thereafter, growing cells were harvested by cooled centrifugation (4 ${ }^{\circ} \mathrm{C}$ ) at $5000 \mathrm{rpm}$ for $30 \mathrm{~min}$. Then, washed with deionized distilled water (DDW) three times, collected in sterile test tubes and resuspended in small amount of DDW. One millilitre was dried in the oven at $100{ }^{\circ} \mathrm{C}$ in order to estimate the dry weight.

\section{Extraction of Cell Walls:}

Bacterial cells were grown in one litter of brain heart infusion broth in shaker incubator $(180 \mathrm{rpm} / \mathrm{min})$ at $37^{\circ}$ $\mathrm{C}$ for $24 \mathrm{hr}$. Extraction of cell walls was accomplished according to the method described by [11].

One hundred $\mathrm{ml}$ of bacterial cultures were boiled in a water bath for 
7 min, and then collected by centrifuged $(7000 \mathrm{rpm} / \mathrm{min})$ at $4{ }^{\circ} \mathrm{C}$ for 8 min. Hot 5\% sodium dodecyl sulphate (SDS) was added to pelleted cells, which were then resuspended and boiled for $25 \mathrm{~min}$. Insoluble material was recovered by centrifugation $\left(7000 \mathrm{rpm} / \mathrm{min}, 20^{\circ} \mathrm{C}, 8\right.$ min) and boiled again in $4 \%$ SDS for 15 min after resuspension. The resulting insoluble wall preparation was then washed with hot distilled water $\left(60{ }^{\circ} \mathrm{C}\right)$ five times until free of SDS. Covalently attached proteins are removed by treatment with $2 \mathrm{mg} / \mathrm{ml}$ of protease for one hour at $60{ }^{\circ} \mathrm{C}$. The walls were then recovered by centrifugation $(7000 \mathrm{rpm} / \mathrm{min}, 8 \mathrm{~min}$, $4^{\circ} \mathrm{C}$ ) washed once in distilled water and suspended in deionized distilled water. One $\mathrm{ml}$ was taken from this suspension for the dry weight extraction.

\section{Biosorption protocol}

Biosorbents (bacterial cells or crude cell walls) were added to 100 $\mathrm{mg} / \mathrm{L}, \mathrm{pH} 5$ and $20 \mathrm{ml}$ of lead solution, in a final concentration reached $0.5 \mathrm{mg}$ (dry wt. biosorbent) / $\mathrm{ml}$ (lead solution), as triplicates, for one hour at $40{ }^{\circ} \mathrm{C}$. Control lead solution (free of Biosorbents) was prepared as well. Afterwards, all lead solutions were centrifuged at $4{ }^{\circ} \mathrm{C}$ at $5000 \mathrm{rpm}$ for 30 min and the lead concentration was estimated in the supernatant using flame atomic absorption spectrophotometer [12]. The amount of biosorbed lead was taken to be the difference between the initial lead concentration and residual lead concentration in supernatant.

\section{Calculations:}

To calculate the amount of sorbent that was added to lead solution to achieve $0.5 \mathrm{mg} / \mathrm{ml}$ as a final concentration, the following equation was adopted [13]:
- Required volume $(\mathrm{ml})=10 /$ Biosorbent concentration (mg dry wt. $/ \mathrm{ml}$ )

The following equation was followed to estimate the initial lead concentration after the addition of the biosorbent [13]:

- Initial lead concentration $(\mu \mathrm{g} / \mathrm{ml})=$ (20 - The added biosorbent volume 120) $\times$ Control concentration

The following equation was used in order to calculate the biosorbed lead concentration [13]:

- Biosorbed lead concentration $(\mu \mathrm{g} / \mathrm{ml})=$ Initial lead concentration residual lead concentration in supernatant.

\section{Fourier Transform Infrared} Spectroscopy analysis:

Fourier transform infrared (FTIR) spectroscopy was used to determine the changes in vibration frequency in the functional groups in the fresh and metal-loaded biosorbents. Samples of $B$. subtilis N1whole cells and cell walls were first mixed with potassium bromide $(\mathrm{KBr})$ and then ground in an agate mortar at an approximate ratio of $1: 10$ for the preparation of pellets (weight of 10 $\mathrm{mg}$ ). The resulting mixture was pressed at 10 tons for $5 \mathrm{~min}$. The background obtained from the scan of pure $\mathrm{KBr}$ was automatically subtracted from the sample spectra. All spectra were plotted using the same scale on the absorbance axis [14].

\section{Statistical analysis}

F-test and LSD at 0.05 probability level were employed.

\section{Results and Discussion:}

\section{Chemical and physical measurements}

Results illustrated in Table 1 showed temperature, $\mathrm{pH}$ and lead concentration, which measured in situ of wastewater in SBMC (Babyl 2 factory). An obvious variation in 
temperature ranged between 19.5 $34.5^{\circ} \mathrm{C}$. However, the difference was smaller in respect of the $\mathrm{pH}$ values; 6.1- 6.4. Also, it can be seen that the concentration of lead in the industrial wastewater of the factory was between $4.5-6.5 \mathrm{mg} / \mathrm{l}$. This variation may be attributed to the difference between the nature of work and production rate.

Table 1: values of Temperature, $\mathrm{pH}$, and lead concentration in wastewater of State Battery Manufacturing Company (Babyl 2 factory)

\begin{tabular}{|c|c|c|c|}
\hline $\begin{array}{c}\text { Sample } \\
\text { no. }\end{array}$ & $\begin{array}{c}\text { Temperature }\left({ }^{\circ} \mathrm{C}\right) \\
\pm \text { standard } \\
\text { deviation }\end{array}$ & $\begin{array}{c}\text { Mean } \\
\mathrm{pH} \pm \\
\text { standard } \\
\text { deviation }\end{array}$ & $\begin{array}{c}\text { Mean Lead } \\
\text { concentration } \\
(\mathrm{mg} / \mathrm{L}) \pm \text { standard } \\
\text { deviation }\end{array}$ \\
\hline 1 & $34.5 \pm 0.1$ & $\begin{array}{c}6.1 \pm \\
0.05\end{array}$ & $6.0 \pm 0.01$ \\
\hline 2 & $21.5 \pm 0.2$ & $6.2 \pm 0.0$ & $6.5 \pm 0.1$ \\
\hline 3 & $20 \pm 0.1$ & $6.1 \pm 0.1$ & $5.0 \pm 0.1$ \\
\hline 4 & $19.5 \pm 0.1$ & $6.4 \pm 0.2$ & $4.5 \pm 0.3$ \\
\hline Mean & 23.87 & 6.2 & 5.5 \\
\hline Range & $19.5-34.5$ & $6.1-6.4$ & $4.5-6.5$ \\
\hline
\end{tabular}

Each datum is the mean of triplicate.

The ability of Bacterial Isolates to bioremove Lead from aqueous solutions

Results given in table 2 show the ability of gram positive isolates to bioremove Lead from aqueous solution, and illustrates a significant difference $(\mathrm{P}<0.05)$ between bacterial isolates in Lead bioremoval from aqueous solution.

The highest lead bioremoval capacity was achieved by $B$. subtilis $\mathrm{N} 3$ which removed $74.5 \pm 0.7 \mathrm{mg} / \mathrm{l}$ and the lowest lead bioremoval capacity was accomplished by $B$. cereus N6 resulting in $1.6 \pm 0.7 \mathrm{mg} / \mathrm{l}$.

Table 2: Lead bioremoval by Bacillus isolates (whole cell)

\begin{tabular}{|c|c|c|}
\hline $\begin{array}{c}\text { Isolate } \\
\text { code }\end{array}$ & Bacterial isolate & $\begin{array}{c}\text { Mean Biosorbed lead } \\
\text { concentration(mg/l) } \pm \text { standard } \\
\text { deviation }\end{array}$ \\
\hline $\mathrm{N} 1$ & Bacillius subtilis & $27.6 \pm 1.4 \mathrm{a}$ \\
\hline $\mathrm{N} 2$ & Bacillius subtilis & $10.1 \pm 1.7 \mathrm{~b}$ \\
\hline $\mathrm{N} 3$ & Bacillius subtilis & $74.5 \pm 0.7 \mathrm{c}$ \\
\hline $\mathrm{N} 4$ & Bacillius cereus & $8.93 \pm 2.8 \mathrm{~b}$ \\
\hline $\mathrm{N} 5$ & Bacillius cereus & $8.1 \pm 3.5 \mathrm{~b}$ \\
\hline $\mathrm{N} 6$ & Bacillius cereus & $1.6 \pm 0.7 \mathrm{~d}$ \\
\hline
\end{tabular}

Each datum is the mean of triplicates. Data with similar letters have insignificant difference. $\mathrm{LSD}=6.45$
It is evident, from tables 2 the variation in bioremoval capacity of lead even among the isolates of the same species like $B$. subtilis isolates (N1, N2 and N3), which showed significant differences $(\mathrm{P}<0.05)$ in bioremoval capacities 27.6, 10.1 and $74.5 \mathrm{mg} / 1$, respectively. Similar significant differences were found in case of the isolates N4, N5 and N6 which belong to $B$. cereus had bioremoval capacities reached 8.93, 8.1 and $1.6 \mathrm{mg} / \mathrm{l}$, respectively. The above mentioned findings suggest that lead bioremoval by bacteria is neither connected nor limited to a specific species, i.e. it is a strain-specific rather than a species-specific process. Fahad[13] ensured the existence of a wide diversity in the ability of microorganism in biosorption of metal ions, and mentioned that it is not restricted to a specific taxon, where the variation extended to include members of the same genus, and that was shown in this study as well. Undoubtedly, we can distinguish that $B$. subtitlis is more efficient bacteria in lead bioremoval from aqueous solution, and many studies recommended the using of Bacillus spp. in biosorption process $[15,16,17,6]$.

The ability of Bacterial Cell Walls to Biosorb Lead from aqueous Solutions

Table 3 demonstrates the ability of gram positive cell walls to biosorb lead from aqueous solution. However, it is also illustrating significant differences $(\mathrm{P}<0.05)$ in this ability. The highest amount of lead was biosorbed by the walls of $B$. subtilis $\mathrm{N} 1$ giving biosorption mean of $77.7 \pm 0.3 \mathrm{mg} / \mathrm{l}$ and the lowest biosorption capacity was attained by the walls of $B$. cereus N6 which biosorbed $(6.7 \pm 2.1 \mathrm{mg} / \mathrm{l})$. bioremoval was due to bisorption rather than via bioaccumulation so when the cell walls extracted the outcome of uptake was not affected at all. 
Table 3: Biosorption of lead by Bacillus spp. cell walls

\begin{tabular}{|c|c|c|}
\hline $\begin{array}{c}\text { Isolate } \\
\text { code }\end{array}$ & Bacteria & $\begin{array}{c}\text { Mean Biosorbed lead } \\
\text { concentration(mg/l) } \\
\text { standard deviation }\end{array}$ \\
\hline $\mathrm{N} 1$ & $\begin{array}{c}\text { Bacillius } \\
\text { subtilis }\end{array}$ & $77.7 \pm 0.3$ \\
\hline $\mathrm{N} 2$ & $\begin{array}{c}\text { Bacillius } \\
\text { subtilis }\end{array}$ & $18.6 \pm 1.2$ \\
\hline $\mathrm{N} 3$ & $\begin{array}{c}\text { Bacillius } \\
\text { subtilis }\end{array}$ & $9.5 \pm 0.7$ \\
\hline $\mathrm{N} 4$ & $\begin{array}{c}\text { Bacillius } \\
\text { cereus }\end{array}$ & $42.4 \pm 0.6$ \\
\hline $\mathrm{N} 5$ & $\begin{array}{c}\text { Bacillius } \\
\text { cereus }\end{array}$ & $9.9 \pm 0.9$ \\
\hline $\mathrm{N} 6$ & $\begin{array}{c}\text { Bacillius } \\
\text { cereus }\end{array}$ & $6.7 \pm 2.1$ \\
\hline
\end{tabular}

Each datum is the mean of triplicates. Data with two similar letters have insignificant difference. $\mathrm{LSD}=10.4$

From figure 1, it was revealed that the cell walls of some gram positive isolates B. subtilis $\mathrm{N} 1, B$. subtilis $\mathrm{N} 2$, B.cereus $\mathrm{N} 4$ and $B$. cereus N6 achieved higher uptake capacity than their spouses of the whole cells. The reason behind such result could be attributed to: 1) more reactive sites were exposed both in the outer as well as the inner interface of the cell wall. 2) The number of cell walls, consequently the reactive sites, will be higher than those found in whole cells at the same weight unit.

Concerning the isolate $B$. cereus $\mathrm{N} 5$, both the whole cell and cell walls showed insignificant differences $(\mathrm{P}>0.05)$ in bioremoval capacity. This result could be due to the biosorption and bioaccumulation of lead, which were probably the same but the increased number of reactive sites in the extracted walls compensated such shortfall or it could be ascribed to the In regard to the isolates $B$. subtilis $\mathrm{N} 3$, the lead uptake was higher in whole cells than cell walls and that can be simply explained as these isolates removed lead ions by bioaccumulation process.

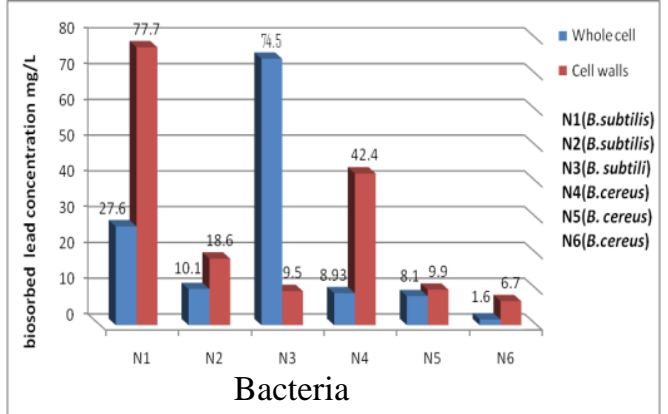

Fig.(1): A comparison between whole cell and cell wall of gram positive bacteria in lead bioremoval. LSD $=$ 5.3.Each datum is the mean of triplicates.

Generally, the present results has shown that higher removal of lead by gram positive bacteria this result is in agreement with many previous studies which reported that $B$. subtilis is very efficient in uptaking heavy metal $[18,19,20]$.

[20].mentioned that Glycoproteins present on the outer side of gram positive bacterial cell walls suggesting to have more potential binding sites for heavy metals than the phospholipids and LPS and hence may be responsible for the observed difference in capacity.

\section{Fourier Transform Infrared (FTIR) Spectroscopy}

Figures 2 and 3 showed the spectrum of FTIR we can evidently see the chemical groups those linked with lead ions which were Carboxyl (1710 $\left.-1740 \mathrm{~cm}^{-1}\right)$, Hydroxyl $\left(3400 \mathrm{~cm}^{-1}\right)$, Amide $\left(3400 \mathrm{~cm}^{-1}\right)$ and Carbonyl $\left(1700 \mathrm{~cm}^{-1}\right)$, these are almost similar in the whole cell and cell walls of both types of bacteris (i.e. gram positive isolates).

Apparently, the binding of lead ions to the anionic groups (carboxyl, hydroxyl and Carbonyl) may be expected due to the static electrical attraction between the ions and the given functional groups. Nevertheless, in case of positively charged groups (amides), the resultant binding could be due to mediation of negative ions by 
a mechanism named complexation [21,22] .

In B. subtilis and other Grampositive microorganisms, the carboxyl groups of D-glutamic acid residues of the peptidoglycane are the most potent metal scavengers and play a meaningful role in the biosorption [16]. However, teichoic and teichronic acids are important binding sites in gram positive bacteria [12].
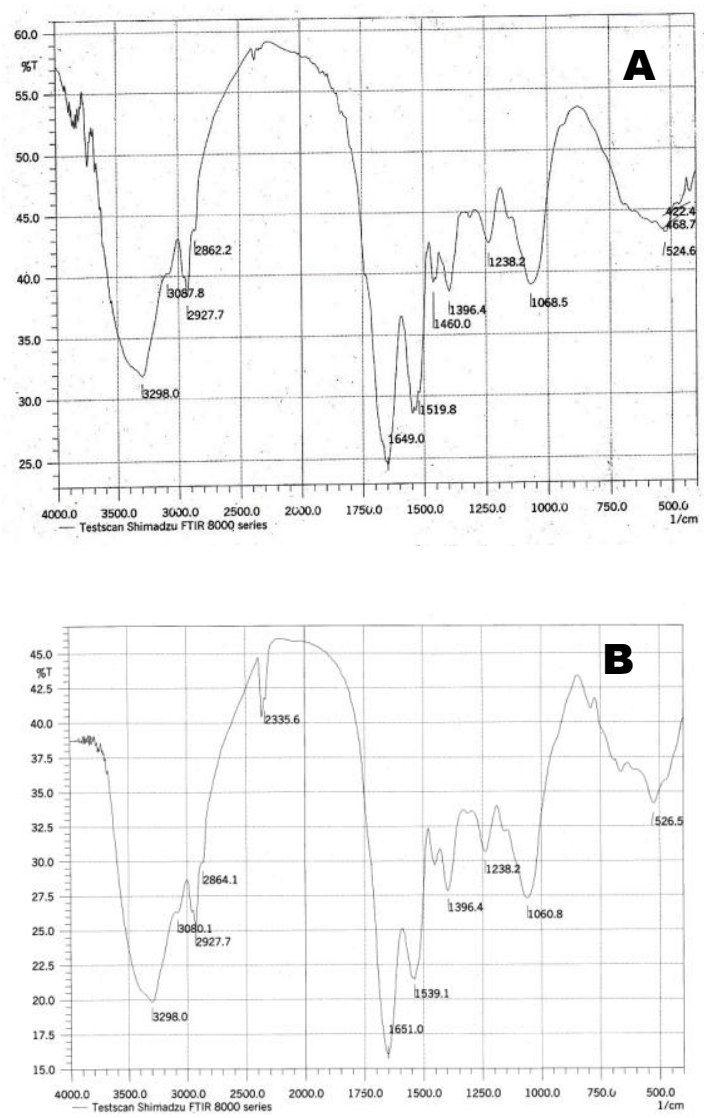

Fig.(2) : FTIR Analysis of Bacillus subtilis N1 whole cell. A: Unloaded. B: Loaded with Lead
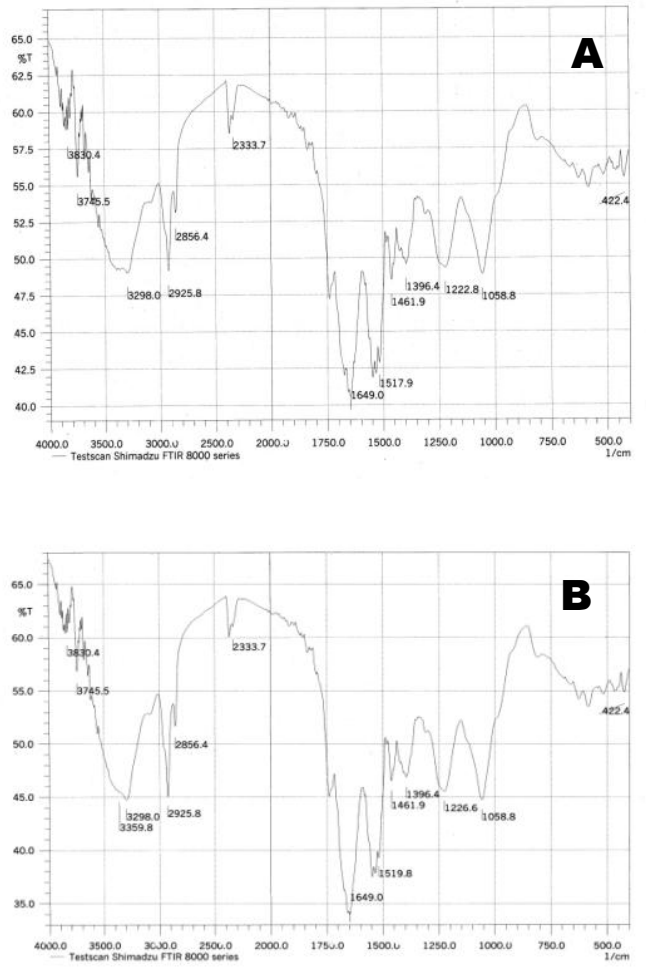

Fig.(3): FTIR Analysis of Bacillus subtilis $\mathrm{N} 1$ cell wall. A: Unloaded.

\section{B: Loaded with Lead}

\section{References}

1.Ahalya, N.; Ramachandara, T.V and Kanamadi, R.D. 2003. Biosorption of heavy metals. Res.J. Chem. Environ .7(4):71-79.

2.Bulut, Y. and Baysal, Z. 2006. Removal of $\mathrm{pb}(\mathrm{II})$ from wastewater using Wheat Bran. J. Environ. Manag. 78(2):107-113.

3.Paknikar, K.M., Pethkar, A.V; Puranik, P.R. 2003. Bioremediation of metalliferous Wastes and products using Inactivated Microbial Biomass. Indian J. Biotechnol. 2(3): 426-443.

4.Vacchio, A.; Fionoli, C. and Disimine, D. 1998. Heavy metal biosorption by bacterial cells. Fresenius.J. Anal. Chem. 361(4):338-342.

5.Voleskey, B. 2004.Sorption and biosorption. Sorbex, INC, St.Lambert, Quebec pp36-103.

6.Tarangini, K. 2009. Biosorption of Heavy Metals using Individual and Mixed cultures of Pseudomonas 
aeruginosa and Bacillus subtilis. Master of technology thesis. National institute of technology, Orissa, India.

7.Vijayaraghavan, K.Yun, Y. 2008. Bacterial biosorbents and biosorption Adv.Biotechnol. 26(3):266-291.

8.Nester, E. , Anderson, O. Robert, J. Pearsall, N. and Nester, M. 2001. Microbiology ahuman perspective $3^{\text {rd }}$ ed .. Mc Graw -Hill Education . New York, pp.61-65.

9.American Protection Health Agency (APHA). 1998. Standered methode for examination of water and waste water $20^{\text {th }} \mathrm{Ed}$.

10. Garrity, G., Brenner, D., Krieg,N., and Staley, J. 2004. Bergey's manual of Systematic Bacteriology, Second Edition. Springer.

11. Atrith, A.; Bacher, G.; Allmaier, G. and Williamson, M.P. 1999. Analysis of Peptidoglycan Structure from Vegetative Cell of Bacillus subtilis 168 and Role of PBP 5 in Peptidoglycan Maturation. J. Bacteriol. 181(13):3956-3966 .

12. Ilhan, S.; Cabuk, A.; Filik ,C. and Caliskan ,F.(2004). Effect of Pretreatment on biosorption of heavy meatals by fungal biomass. Turkya univ.J.Sci.5(1):11-17.

13. Fahad, H.J. 1994.A study of efficiency of different microorganisms in thorium sorption from aqueous solutions .M.Sc.Thesis .College of science, Baghdad University, Iraq.

14. Paul, S.B. and Lei, P. R. 2006. Biosorption of $\mathrm{Pb}$ (II) by Bacillus cereus M116 immobilized in calcium alginate gel. J. Hazard. Subst. Res. 5: 2-13.
15. Odokuma, L.O. and Abah, A.E. 2003. Heavy metal biosorption by three bacterial isolated from a tropical river .Global .Jul. Environ. Sci.2(2):98-101.

16. Tawfik, Z., Abu Shady, M., and Haytham,M. 2005.Uranium uptake by some locally isolated and some reference bacterial species.Acta. Pharm. 55:93-105.

17. Khanafari, A., Eshghdoost, S; and Mashinchian, A. 2008.Removal of lead and chromium from aqueous solution by Bacillius circulans biofilm.Iran. J.Environ. Health.Sci. Eng. 5(3):195-200.

18. Beveridge, T.J. and Fyfe, W.S. 1985. Metal fixation by bacterial cell wall. Can. J. Earth. Sci.22(12):18931898.

19. Abdul kareem, U.S.2006. Bioremoval of Zinc by cell wall of bacteria Bacillus subtilis. M. Sc Thesis. College of science, Baghdad University. Iraq.

20. Gupta, R., Ahuja, P., Khan, S., saxena , R. K. and Mohapatra, H. 2000. Microbial biosorbents: Meeting challenges of heavy metal Pollution in aqueous solutions, Current Sci. 78 (8): 967-973.

21. Davis, T. A., Volesky, B. and Mucci, A., 2003. A review of the biochemistry of heavy metal biosorption by brown algae. Water. Res., 37 (18), 4311-4330.

22. Mahmoud, B. 2005. Bioremoval of chromium from industrial wastewater. M. Sc Thesis. College of science, Baghdad University. Iraq. 


\section{الازالة الحياتية للرصاص بوساطة .Bacillus spp المعزولة من مياه الفضلة الصناعية}

*ارث جبار فه المنخوري

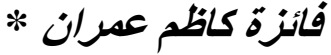

* جامعة بغداد، كلية العلوم، قسم علوم الحياة

الخلاصة:

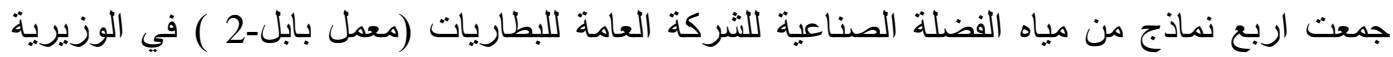

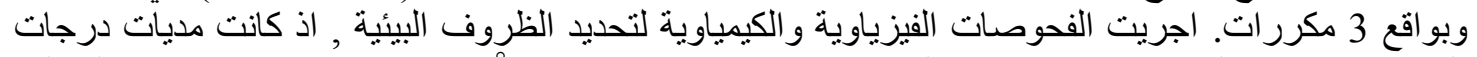

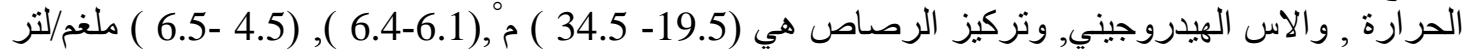

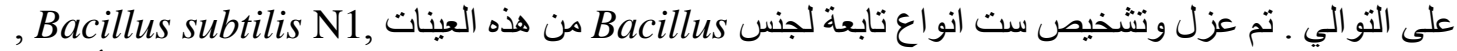

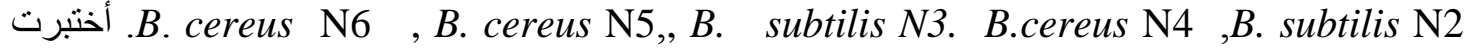

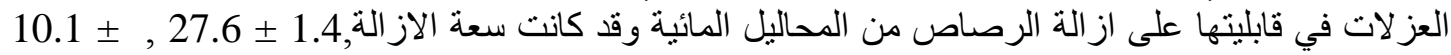

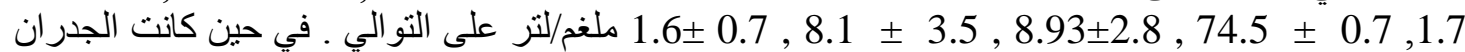

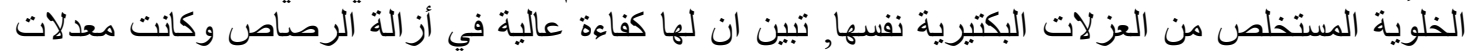

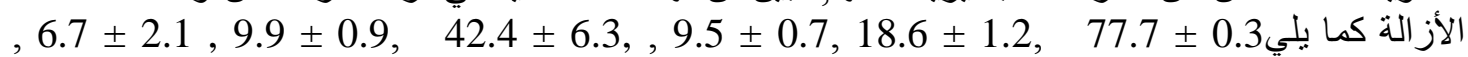

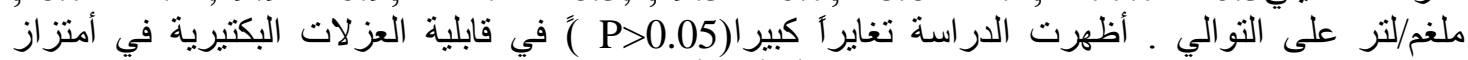

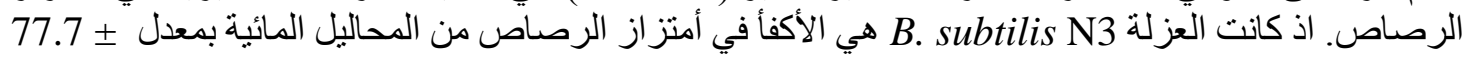

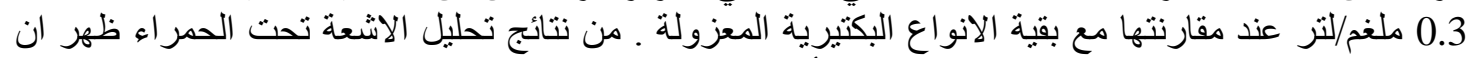

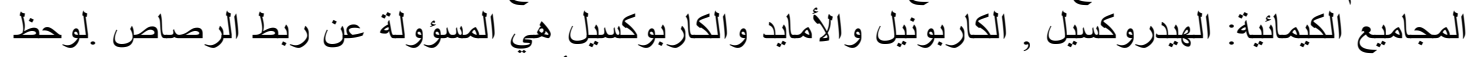

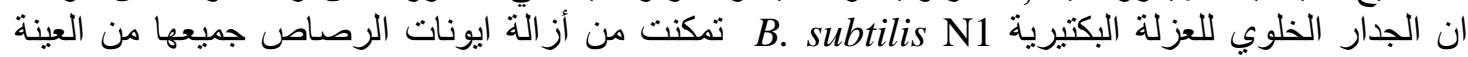

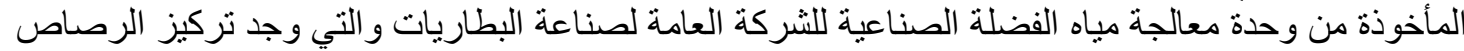
فيها 4.5 ملغم/لتر 